\title{
ANATOMIZING THE SCEPTICAL CHYMIST: ROBERT BOYLE AND THE SECRET OF HIS EARLY SOURCES ON THE GROWTH OF METALS
}

\author{
HIRO HIRAI \\ Centre for History of Science, University of Ghent
}

HIDEYUKI YOSHIMOTO

Tokyo University of Foreign Studies

\begin{abstract}
Although the "sceptical chymist" Robert Boyle is generally known as an experimental natural philosopher, he was also the child of a culture of bookish erudition. By quoting diverse classical, medieval, Renaissance and contemporary authors, he gave to his readers the impression that he could avail himself of a very wide range of sources. In some cases, however, his apparent erudition was largely dependant on contemporary doxographical commonplace-books. This article unveils one of these books, Johann Gerhard's Decas quaestionum physico-chymicarum de metallis (1643), which served Boyle as his secret source for past authoritative views on the issue of the growth of metals. We also discuss the way in which he manipulated the information he found in this book in order to increase the credibility of his own discourse.
\end{abstract}

\section{Introduction}

In order to understand an author's thought in its philosophical and historical context, it is very important to trace the sources on which he founded his ideas. It is through this procedure of Quellenforschung that one can really measure his debt to forerunners as well as his originality. In the case of the "sceptical chymist" Robert Boyle (1627-1691), even a superficial reading of his writings, which have recently been edited by Michael Hunter and Edward B. Davis, will strike us for the erudition that is present even in his early scientific writings. ${ }^{1}$ The knowledge he displays

* We acknowledge Larry Principe, Myriam Dennehy and the friends of bibliotheca hermetica, M. Iwata, H. Ogawa, Y. Ohashi, A. Murase, Y. Akae and Y. Kikuchi for their help in the preparation of the present paper. Its French version will be published in La philosophie naturelle de Robert Boyle (Paris: Vrin, forthcoming).

1 Michael Hunter and Edward B. Davis (eds.), The Works of Robert Boyle (Lon- 
is based not only on the classical authors but also on those of the Renaissance and of his own time. It is true that Boyle was scrupulous in gathering information from his own experiments as well as from friends and colleagues. Fascinated by strange phenomena, he eagerly collected precise and detailed testimonies about them, following a Baconian program for experimental natural history. ${ }^{2}$ But this aspect has been so much emphasized that one sometimes forgets that he was also the child of a culture of bookish learning. Indeed, it appears that he was widely read in diverse genres of literature such as pharmacopeias, travelers' memoirs, natural histories, medical and chymical recipes, etc.

But a simple question springs to mind. How could the young Boyle have gathered such an amount of knowledge in a very short time after 1649? Is there any possibility that he used some sort of guidebook or commonplace-book, that is, compendia of a doxographical nature? ${ }^{3}$ While this question will continue to guide our collaborative research, the present article provides a first, affirmative answer concerning Boyle's use of a precise doxographical source in his discussion of the problem of the growth of metals, one of his favorite subjects.

\section{“Observations about the Growth of Metals" (1674)}

In 1674, Boyle published his Hidden Qualities of the Air, which is included in the eighth volume of the new edition of his works. ${ }^{4}$ In this treatise, he describes, as a proof for the existence of the air's hidden qualities, the growth of metals which are extracted

don, 1999-2000). For his letters, see Michael Hunter et al. (eds.), The Correspondence of Robert Boyle (1636-91) (London, 2001). To avoid the erroneous distinction between "chemistry" and "alchemy," we use the term "chymistry" in our discussion, following the suggestion of William R. Newman and Lawrence M. Principe, "Alchemy vs. Chemistry: The Etymological Origins of a Historiographic Mistake," Early Science and Medicine 3 (1998), 32-65.

See Lorraine Daston and Katharine Park, Wonders and the Order of Nature, 1150-1750 (New York, 1998). On his Baconian program, see Rose-Mary Sargent, "Robert Boyle's Baconian Inheritance," Studies in History and Philosophy of Science 17 (1986), 469-86; ead., The Diffident Naturalist: Robert Boyle and the Philosophy of

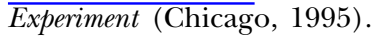

3 On commonplace-books, see especially Francis Goyet, Le sublime du "lieu commun": l'invention rhétorique dans l'antiquité et à la Renaissance (Paris, 1996); Ann Moss, Printed Commonplace-Books and the Structuring of Renaissance Thought (Oxford, 1996).

${ }^{4}$ Boyle, Hidden Qualities of the Air (London, 1674), 1-71 (Works, VIII, 121-42). 
from the mines and are exposed to the air. ${ }^{5}$ However, as he finds it inappropriate to develop a long discussion on the phenomenon at this point, he appends a few pages of observations, apparently based on his reading notes. The piece is entitled "Observations about the Growth of Metals in their Ore Exposed to the Air." He says that this piece is closely related to his essay on the regeneration of salt, which is included in Certain Physiological Essays (London, 1661). ${ }^{7}$ Despite some revisions he introduced for its publication, its origin lies thus in the early phase of his scientific career, around 1660 .

Boyle states that the object of this piece is not to decide whether metals grow in the bowel of the earth like subterranean plants, the question traditionally discussed by alchemists, but to show that metals extracted and exposed to the air increase their weight or volume and that a substance which was previously not a metal turns into one. However, since he estimates that the experiments required to achieve this purpose are too difficult, he satisfies himself by "observing" the testimonies found in the writings of mineralogists, travelers and the other authors "of good credit."

First, Boyle gives some reports on the growth of tin ore in a mine that had once been emptied by miners and had naturally filled again in the course of time. His source of information remains unknown. ${ }^{8}$ Next, he takes up the case of lead. He suggests that the growth of lead ore is more visible than that of other metals. In this account, he gives two quotations in Latin. In this case, he clarifies the books that serve as his sources. For the first one, he even gives the page number of the copy in his possession. This treatise is the Decas quaestionum physico-chymicarum...

5 Boyle, Hidden Qualities, 39 (Works, VIII, 132-3).

6 Boyle, "Observations of the Growth of Metals," 1-25 (Works, VIII, 145-52).

7 On Boyle's sources for some crucial chymical themes in his Certain Physiological Essays, see Hiro Hirai, "Quelques remarques sur les sources de Robert Boyle en guise du compte rendu de la nouvelle édition de son œuvre," Archives internationales d'histoire des sciences 53 (2003), 303-18.

8 Edward Jorden (1569-1632) reports a case of tin ore's growth in Cornwall in his A Discourse of Naturall Bathes and Minerall Waters (London, 1631), 52. On Jorden, see Allen G. Debus, "Edward Jorden and the Fermentation of the Metals: An Iatrochemical Study of Terrestrial Phenomena," in Cecil J. Schneer (ed.), Toward a History of Geology (Cambridge MA, 1969), 100-21; David R. Oldroyd, "Some Neo-Platonic and Stoic Influences on Mineralogy in the Sixteenth and Seventeenth Centuries," Ambix 21 (1974), 128-56, esp. 146-7; Hiro Hirai, Le concept de semence dans les théories de la matière à la Renaissance: de Marsile Ficin à Pierre Gassendi (Brepols, 2005), 455. 
de metallis (Tübingen, 1643) written by Johann Gerhard (1598/ 99-1657), a fairly unknown professor of practical medicine at the Protestant university of Tübingen and several times rector there. ${ }^{9}$ A comparison of the two texts documents the faithfulness of Boyle's quotation.

$$
\text { Boyle, Works, VIII, } 147 .
$$

"Fessularum mons in Hetruria, says Boccatius Certardus, who delivers it as a most approved truth, Florentiae Civitati imminens, lapides plumbarios habet, qui si excidantur brevi temporis spatio novis incrementis instaurantur." J. Gerhard. in Decade quaestionum, pag. m. 22.
Gerhard, Decas, i, 22.

"Fessularum mons in Hetruria, Florentiae civitati imminens, lapides plumbarios habet, qui si excidantur, brevi temporis spatio, novis incrementis instaurantur, ut tradit Boccatius Certaldus, qui id compertissimum esse scribit."

Without any interval, Boyle goes on to quote his second testimony for the growth of lead, which is taken from the De ortu et causis subterraneorum (Basel, 1546) of Georg Agricola (1494-1555), the sixteenth century's most important writer on the mining world. ${ }^{10}$ However, exactly the same extract is also found in Gerhard's text. When we compare the wording of the three men, one is led to suspect that Boyle follows Gerhard rather than Agricola here. ${ }^{11}$

\begin{tabular}{|c|c|c|}
\hline $\begin{array}{l}\text { Boyle, Works, VIII, } 147 . \\
\text { "Tu subtilius ne quaeras (says } \\
\text { Agricola, speaking of the } \\
\text { growth of mines in general) sed } \\
\text { tantummodo refer animum ad } \\
\text { cuniculos, \& considera, eos } \\
\text { adeo interdum memoria } \\
\text { hominum in angustum venisse, } \\
\text { ut aliqua sui parte nullum aut } \\
\text { admodum difficilem praebeant } \\
\text { transitum, cum eos satis late } \\
\text { agere soleant fossores, ne } \\
\text { transituros impediant. In tales } \\
\text { autem angustias sunt adducti } \\
\text { propter accretionem materiae } \\
\text { ex qua lapis est factus." }\end{array}$ & $\begin{array}{l}\quad \text { Agricola, De ortu, } \mathrm{V}, 63 . \\
\text { Atque isti haec subtilius non } \\
\text { quaerant, sed referant animum } \\
\text { ad cuniculos, \& considerent eos } \\
\text { adeo interdum memoria } \\
\text { hominum in angustum venisse, } \\
\text { ut aliqua sui parte nullum aut } \\
\text { admodum difficilem praebeant } \\
\text { transitum: cum eos satis late } \\
\text { soleant agere fossores, ne } \\
\text { transituros impediant. In tales } \\
\text { autem angustias sunt adducti } \\
\text { propter accretionem materiae, } \\
\text { ex qua lapis est factus. }\end{array}$ & $\begin{array}{l}\text { "[...] At qui tu, subtilius ne } \\
\text { quaeras, sed tantummodo refer } \\
\text { animum ad cuniculos, \& } \\
\text { considera eos, adeo interdum } \\
\text { memoria hominum in angustum } \\
\text { venisse, ut aliqua sui parte } \\
\text { nullum, aut admodum difficilem } \\
\text { praebeant transitum, cum eos } \\
\text { satis late agere soleant fossores, } \\
\text { ne transituros impediant. In } \\
\text { tales autem angustias sunt } \\
\text { adducti propter accretionem } \\
\text { materiae, ex qua lapis est } \\
\text { factus. [...]." Hactenus } \\
\text { Agricola. }\end{array}$ \\
\hline
\end{tabular}

9 We have used the following edition: Johann Gerhard, Decas quaestionum physico-chymicarum selectiorum et graviorum, omnibus tam Hermeticae quam Peripateticae philosophiae studiosis scitu necessariarum, Lectu jucundarum atque utilium de metallis (Tübingen, Philibert Brunn, 1643). On Gerhard, see John Ferguson, Bibliotheca chemica (Glasgow, 1906), I, 311-3; Ernst Conrad, Die Lehrstühle der Universität Tübingen und ihre Inhaber (1477-1927) (Tübingen, 1960), 29, 97.

${ }^{10}$ On this treatise, see Hirai, Le concept de semence, 111-34. We have used the first edition.

11 Notable differences will be underlined throughout. 
Boyle thereupon moves on to the report of a "gentleman," a chymist and owner of lead mines, who has never observed any such growth of lead ore. With this quotation, Boyle expresses his scepticism with regard to this phenomenon and tries to give a mechanical explanation. According to him, the water surrounding the mine, which imbibes the neighboring earth, expands when turning into ice, making the ore crack and thereby producing a visible expansion of the lead ore. Although with this argument, Boyle does not aim to deny the growth of the ore itself but to contribute to further considerations, he estimates his proof more suitable than that given by some writers, who claim that tin roofs should be replaced by brass ones because over time, the buildings will not be able to support the increasing weight of tin any longer. Once again, Boyle mentions Johann Gerhard (always with a page number), stating that this example is used by some mineralogists, among others "the learned Jo. Gerhardus," as a proof for the growth of metals. ${ }^{12}$ But he believes that it involves a misunderstanding. For him, the increase in weight of tin roofs should not be attributed to the real growth of the metal itself, but to the saline corpuscles evaporating from the timber of these buildings which, by attaching themselves to the roof, produce a kind of alloy like ceruse and thereby increase the roof's weight. Boyle therefore wonders whether the famous testimony of Galen, to which these authors often refer, is a reliable argument to prove the growth of the metal. We note that the new edition of Boyle' Works identifies neither "these writers" nor the locus of Galen's report. ${ }^{13}$ But if we return once more to the text of Gerhard, we find all the missing evidence. Following the testimony of Pliny the Elder on the growth of lead, Gerhard refers to Galen's account of the volume increase of lead joints for statues, in his treatise On the faculties of simple drugs, IX, 23. ${ }^{14}$ In Gerhard's eyes, Galen's report is confirmed by several writers for the case of leaden roofs of temples. He adds to this Thomas of Cantimpré (ca. 1200-ca. 1270) and Vincent of Beauvais (?-1264), who talk about a more rapid growth of lead

12 Boyle, "Growth of Metals," 11 (Works, VIII, 148).

13 Boyle, "Growth of Metals," 13 (Works, VIII, 148, n. a-b).

14 Galen, De simplicium medicamentorum facultatibus, IX, 23 (Kühn, XII, 230-1). Cf. Ludwig Israelson, Die materia medica des Klaudios Galenos (Dorpat, 1894), 1678. On Galenic pharmacology in general, see Armelle Debru (ed.), Galen on Pharmacology: Philosophy, History and Medicine (Leiden, 1997). 
outside the mines than inside them, as well as Girolamo Cardano (1501-1576), who speaks of an increase in weight of lead in the process of calcination. ${ }^{15}$ Then, facing an objection made by Gabriele Falloppio (1523-1562) against Galen, Gerhard quotes Andrea Cesalpino (1524/25-1603). According to Gerhard, Cesalpino agrees with alchemists like Petrus Bonus, the author of the famous Margarita pretiosa novella (ca. 1330), and wonderfully shows the harmony of Aristotle and Galen with respect to the growth of lead. ${ }^{16}$ For Gerhard, a humid exhalation surrounding lead in damp places produces some saltiness around the lead and, through this saltiness, the lead is increased. Furthermore, lead itself attracts a vaporous substance which also contributes to its growth. In order for these two causes to join together for the growth of lead, it is necessary that a certain vegetative power, which lies hidden inside the substance of lead, is activated. From this chain of testimonies, we can reasonably suppose that Boyle had in mind all these quotations made by Gerhard for his "several writers."

In Boyle's account, lead is followed by iron. As far as the mines of his own country are concerned, Boyle does not find anything particular which might confirm the growth of iron ore. However, he does find some foreign affirmative testimonies, especially concerning the famous mine of the island of Elba. He states that not only the Ancients like Strabo and Pliny, but also some modern authors of "very good credit" such as Falloppio and Cesalpino, attest to this phenomenon. ${ }^{17}$ He quotes Cesalpino first. Here again, let us compare his quotation with Gerhard's text:

15 Gerhard, Decas, i, 22-3. Cf. Thomas of Cantimpré, Liber de naturis rerum, XV, vii, 9; Vincent of Beauvais, Speculum naturale, VII, xl; Cardano, De subtilitate, V (ed. Lyon, 1580, 197). On the pan-vitalist mineralogy of Cardano and Albertus Magnus as his source, see Hirai, Le concept de semence, 136-56.

16 Gerhard, Decas, i, 24. Cf. Cesalpino, De metallicis, III, vii. For the De metallicis of Cesalpino, we have used its second edition (Nuremberg, 1602). On this treatise, see Hirai, Le concept de semence, 159-75. On Petrus Bonus, see DSB 10 (1974), 554-6; Lynn Thorndike, A History of Magic and Experimental Science (New York, 1934), III, 147-62; Chiara Crisciani, "The Conception of Alchemy as Expressed in the Pretiosa margarita novella of Petrus Bonus," Ambix 20 (1973), 165-81.

17 Cf. Strabo, Geography, V, ii, 6; Pliny, Natural History, III, vi, 81; XXXIV, xli, 142. On the classical ideas on the fertility of mines, see Robert Halleux, "Fécondité des mines et sexualité des pierres dans l'Antiquité gréco-romaine," Revue belge de philologie et d'histoire 49 (1970), 16-24. 


\begin{tabular}{|c|c|c|}
\hline $\begin{array}{l}{[\ldots] \text { the latter speaks thus: }} \\
\text { "Vena ferri copiosissima est in } \\
\text { Italia, ob eam nobilitata, Ilva, } \\
\text { Tyrreni maris insula, incredibili } \\
\text { copia, etiam nostris temporibus } \\
\text { eam gignens: Nam terra, quae } \\
\text { eruitur dum vena effoditur, tota } \\
\text { procedente tempore in venam } \\
\text { convertitur." }\end{array}$ & $\begin{array}{l}\text { Vena ejus [ferri] copiosissima } \\
\text { est in Italia: ob eam nobilitata } \\
\text { Ilva Tyrrheni maris insula, } \\
\text { incredibili copia etiam nostris } \\
\text { temporibus eam gignens: nam } \\
\text { terra quae eruitur, dum vena } \\
\text { effoditur, tota procedente } \\
\text { tempore in venam convertitur. }\end{array}$ & $\begin{array}{l}\quad \text { Gerhard, Decas, i, } 17 . \\
\text { Attestantur idem multo } \\
\text { luculentius Caesalpinus de } \\
\text { metall. lib. 3. cap. 6.: "Vena, } \\
\text { inquiens, ferri copiosissima est } \\
\text { in Italia, ob eam nobilitata Ilva, } \\
\text { Tyrrheni maris insula } \\
\text { incredibili copia, etiam nostris } \\
\text { temporibus eam gignens: Nam } \\
\text { terra, quae eruitur, dum vena } \\
\text { effoditur tota, procedente } \\
\text { tempore in venam convertitur." }\end{array}$ \\
\hline
\end{tabular}

Although we may not draw any definitive conclusion from this comparison alone, let us for the time being just take note of the fact that the texts are almost identical. After Cesalpino, Boyle quotes Agricola without mentioning the fact that Gerhard also quotes the same piece only a few lines after the quotation from Cesalpino. ${ }^{18}$ The identical omission of a phrase from Agricola's original sentence shows an evident parallel between Boyle and Gerhard, so that we may suppose that Boyle used only the latter text.

\begin{tabular}{|c|c|c|}
\hline Boyle, Works, VIII, 149. & $\begin{array}{c}\text { Agricola, De veteribus et novis } \\
\text { metallis, II, } 413 \text {. }\end{array}$ & Gerhard, Decas, i, 17. \\
\hline $\begin{array}{l}\text { And the experienc'd Agricola } \\
\text { gives us the like account of a } \\
\text { place in his country, Germany, } \\
\text { "In Lygiis, says he, ad Sagam } \\
\text { oppidum in pratis eruitur } \\
\text { ferrum, fossis ad altitudinem } \\
\text { bipedaneam actis. Id decennio } \\
\text { renatum denuo foditur, non } \\
\text { aliter ac Ilvae ferrum." }\end{array}$ & $\begin{array}{l}\text { Verum in Lygiis ad Sagam } \\
\text { oppidum e pratis eruitur ferrum, } \\
\text { fossis ad altitudinem } \\
\text { bipedaneam actis. Nec enim } \\
\text { propter abundantiam aquarum } \\
\text { altius agi possunt. Id decennio } \\
\text { renatum denuo foditur, non } \\
\text { aliter ac Ilvae ferrum. }\end{array}$ & $\begin{array}{l}\text { Ipse [Agricola] enim eodem } \\
\text { lib. } 2 \text { cap. } 15 \text { refert: "in Lygiis } \\
\text { ad Sagam oppidum in pratis } \\
\text { erui ferrum, fossis ad } \\
\text { altitudinem bipedaneam actis. } \\
\text { Id decennio renatum denuo fodi } \\
\text { non aliter ac Ilvae ferrum." }\end{array}$ \\
\hline
\end{tabular}

To this, Boyle adds a testimony taken from "the learned Johan. Gerhardus," whose name he now indicates clearly. It is an extract from a German treatise which Gerhard calls Conciones metallicae, without giving the name of its author. Boyle proposes to identify it with the "High-Dutch Sermons" of the Lutheran preacher Johann Mathesius (1504-1565) of St-Joachimsthal, al-

18 Agricola, De veteribus et novis metallis, II (ed. Basel, 1546, 413 = Ausgewählte Werke, VI, 103): "In Schlesien wird bei der Stadt Sagen Eisen aus den Wiesen gewonnen; man zieht Gräben von 2 Fuß Tiefe; wegen der Wasserfülle kann man sie nicht tiefer ziehen. Dieses Eisen wächst nach und wird nach 10 Jahren von neuem gegraben, genau wie das Eisen von Elba.” 
though he confesses that he cannot read Mathesius' language, German. We have so far been unable to identify the original passage in Mathesius' treatise Sarepta oder Bergpostill (Nuremberg, 1562), but it is evident that Boyle relies once more only on Gerhard's treatise. $^{19}$

\begin{tabular}{|c|c|c|}
\hline $\begin{array}{l}\text { Boyle, Works, VIII, } 149 . \\
\text { “Relatum mihi est a metallico } \\
\text { fossore, ad ferrarias, quae non } \\
\text { longe Amberga distant, terram } \\
\text { inanem cum ferri minera } \\
\text { erutam, quam vocant "den } \\
\text { Gummer," mixtam cum } \\
\text { recrementis ferri, quae } \\
\text { appellatur “der Sinder," } \\
\text { congestam in cumulos, instar } \\
\text { magni cujusdam valli solibus } \\
\text { pluviisque exponi, \& decimo } \\
\text { quinto anno denuo excoqui, } \\
\text { eliquarique ferrum tantae } \\
\text { tenacitatis, ut solae laminae } \\
\text { inde procudantur." }\end{array}$ & Mathesius, Sarepta? & $\begin{array}{l}\quad \text { Gerhard, Decas, i, } 18 . \\
\text { "[...] Relatum mihi quoque est } \\
\text { a metallico fossore ad ferrarias, } \\
\text { quae non longe Amberga } \\
\text { distant, terram inanem cum ferri } \\
\text { minera erutam, quam vocant } \\
\text { "den Gummer" mixtam cum } \\
\text { recrementis ferri, quae } \\
\text { appellatur "der Simder" } \\
\text { congestam in cumulos, instar } \\
\text { magni cujusdam valli solibus, } \\
\text { pluviisque exponi, \& decimo } \\
\text { quinto quoque anno denuo } \\
\text { excoqui, eliquarique ferrum } \\
\text { tantae tenacitatis, ut solae } \\
\text { laminae inde procudantur." }\end{array}$ \\
\hline
\end{tabular}

The key to identifying the real author of this quotation is undoubtedly hidden in the German technical terms "Gummer" and "Sinder." But unfortunately, specialized dictionaries of Mathesius' vocabulary have not given us an answer. ${ }^{20}$

After the case of iron, Boyle turns to the growth of silver ore as witnessed in the mines of Potosi in Peru. Here, the editors of Boyle's Works identify his source as the French traveler Melchisédech Thévenot (1620-1692). ${ }^{21}$ With regard to the growth of

19 Jorden, A Discourse of Naturall Bathes, 52, had already attributed the Conciones metallicae to Mathesius. On Mathesius and his Sarepta, see ADB 20 (1884), 586-9; NDB 17 (1990), 369-70; Ernst Göpfert, Die Bergmannssprache in der Sarepta des Johann Mathesius (Strasburg, 1902); Frank D. Adams, The Birth and Development of the Geological Sciences (New York, $\left.{ }^{1} 1938 /{ }^{2} 1954\right)$, 196-8; Franz Kirnbauer, Johannes Mathesius und der Bergbau: Zur 450. Wiederkehr seines Geburtstages (Vienna, 1954); John R. Partington, A History of Chemistry (London, 1961), II, 62-4.

20 The editors of the new edition wrongly render "Amberga" as Hamburg instead of Amberg in Bavaria (Works, VIII, 148 n. a). The dates of birth and death of Gerhard are also wrong. For the Sarepta, they give the reference of 1571 edition probably according to the note of Arthur Rupert Hall and Marie Boas Hall (eds.), The Correspondence of Henry Oldenburg (Madison, 1966), III, 305, n. 1. But there is no particular reason to fix it as such. According to Oldenburg's letter to Boyle (25 November 1667), Boyle seems to have obtained the copy of the Sarepta after this date. Cf. Boyle, Correspondence, III, 612. As for "Sinder," which is now "Sinter" in German, Agricola recorded it as recrementum ferri in his Interpretatio rerum metallicarum (ed. Basel, 1546, 483 = Ausgewählte Werke, III, 37).

21 Boyle, "Growth of Metals," 17-8 (Works, VIII, 150, n. a). 
gold, Boyle seems to have spent much energy, but in vain, in trying to find satisfactory testimonies in the writings of the great travelers. He finds one plausible report by the English traveler Edward Brown (1644-1708), who visited several mines in Hungary and published his memoirs in 1673. As the editors of Boyle's new Works note, the inclusion of this source shows that Boyle reworked his annexed piece on the growth of metals almost until its date of publication. ${ }^{22}$ But that is not all. At the end of the section on gold, Boyle inserts another extract in Latin, which he introduces by writing that "if a late German professor of physick do not misinform" him, Germany affords an eminent testimony on the growth or regeneration of gold. ${ }^{23}$ He does not clarify that he is quoting again from Gerhard, but chooses to refer to him as "a late professor," which allows for the impression that he is relying on a different source. But let us compare his quotation with Gerhard's text.

\section{Boyle, Works, VIII, 151.}

"Nam Corbachi, says he, quae est civitas Westphaliae sub ditione Comitis de Isenborg \& Waldeck, aurum excoquitur ex cumulis congestis, ita ut singulis quadrienniis iterum elaboretur cumulus unus, semper se restaurante natura, etc.."
Gerhard, Decas, i, 19.

"Nam Corbachii, quae est civitas Westphaliae sub ditione Comitis de Isenburg \& Waldeck, aurum excoquitur ex cumulis congestis, ita ut singulis quadrienniis iterum elaboretur cumulus unus, semper se restaurante naturâ, ex insita potentia generativa."

This comparison shows that Boyle seems to have merely copied the text of Gerhard. But there is a supplementary piece of information. His use of the predicate "late" suggests that he was informed of Gerhard's relatively recent death, which occurred in 1657 and thus well after the publication of his treatise Decas quaestionum in 1643. (As for the date 1637, which is sometimes given as the year of his death, it is due to the confusion with another Johann Gerhard (1582-1637), a Lutheran theologian). ${ }^{24}$

Having offered in a postscript two supplementary descriptions of mines in Hungary by Edward Brown, Boyle writes that he has collected even more testimonies, but that his scope is simply to show that the growth of metals is due to exposure to air. With this remark, he ends this annex to the Hidden Qualities of the Air. Although this piece had been reworked for its publication of

22 See the editors' introduction, Works, VIII, xvi.

23 Boyle, "Growth of Metals," 20-1 (Works, VIII, 151).

24 On this theologian, see $A D B 8$ (1878), 767-71; NDB 6 (1971), 281. 
1674, it bears a strong affinity with some of his early writings, published around 1660, such as Certain Physiological Essays and the Sceptical Chymist. The same can be said in relation to his mineralogical manuscripts of the 1660's, which were published for the first time in the thirteenth volume of the new edition of his work. We shall therefore trace the shadow of Gerhard in Boyle's production of this period. Regarding these works, we are inclined to think that when Boyle quotes in Latin the writings of mineralogists like Agricola, Falloppio and Cesalpino, he probably relies exclusively on the extracts collected by Gerhard.

\section{Gerhard in Boyle's Sceptical Chymist}

In order to trace Gerhard's shadow in Boyle's work, it is necessary to examine not only the places where his name is mentioned, but also those where his work is used as an unacknowledged source. In the latter case things are obviously more difficult. As a first step in our investigation, we have therefore limited ourselves to the works where Boyle explicitly refers to Gerhard or, at least, to Continental Renaissance mineralogists such as Agricola, Falloppio, Cesalpino and Mathesius. Special attention has been paid to his discussion of the generation and growth of metals and minerals. Among Boyle's early scientific writings that seem relevant to our purpose (such as Certain Physiological Essays (1661), Sceptical Chymist (1661), Usefulness of Natural Philosophy (1663) and his mineralogical manuscripts), the one that explicitly mentions Gerhard and the other Continental mineralogists is that emblematic work, the Sceptical Chymist, particularly in its sixth and last part, entitled "A Paradoxical Appendix." 25

Carneades, Boyle's spokesman in the dialogue, when denying the role of chymical three principles, first produces an explanation of the constitution of plants and animals and subsequently turns to the mineral kingdom. Since the growth of minerals in the bowel of the earth requires an enormous amount of time, Carneades proposes to rely not on experiments but on "observations," that is to say, on reports and narratives by other writers. ${ }^{26}$ His object is to show that minerals were not created once and 
for all by God in the act of creation, but that they continue to be formed even now. Boyle first presents the case of the growth of stalactites in the French cave called "Goutieres." $\mathrm{He}$ then turns to the growth of diamonds, basing himself on the memoirs of the voyages to the East Indies by the Dutch traveler Jan van Linschoten (1563-1633) and by the Portuguese botanist Garcia da Orta (ca. 1500-ca. 1568), whose name, however, is not given. According to their reports, exhausted diamond mines were found to produce anew after a few years. ${ }^{27}$

As these two testimonies seem sufficient to prove the growth of minerals, Carneades turns to that of metals, quoting successively eight reports from Continental writers "of good note." Most of these narratives are in Latin, which creates a singular atmosphere in this part of the Sceptical Chymist, because there is no other part in this work where such a concentration of Latin quotations is found. Together, these testimonies champion the view that metals were not only formed at the beginning of the world but that they still grow daily. This implies that non-metallic substances continue to turn into metals. Although Carneades finds many statements to this effect in the writings of experienced chymists, he prefers the reports of learned mineralogists who are of good credit and close to miners, thereby avoiding the danger of simply repeating what credulous chymists may have said. ${ }^{28}$ It is clear that he attributes more authority to these "unsuspected writers" than to the chymists.

The first account he gives is by Falloppio, although Boyle does not specify the work in which he found it. However, somewhat surprisingly, the first part of the quotation does not seem to come from Falloppio himself. On the basis of our previous experience, it is worth comparing Boyle not only with Falloppio himself, but also with Gerhard. Here is the result. ${ }^{29}$

27 Boyle, Sceptical Chymist, vi, 357 (Works, II, 347). This story was so pleasing to Boyle that he used it again in his Usefulness, I, iv, 80 (Works, III, 254). On the botanical treatise of Garcia da Orta, see DSB 10 (1974), 236-8; Thorndike, A History of Magic and Experimental Science, VI, 313-5.

28 Boyle, Sceptical Chymist, vi, 357 (Works, II, 348).

29 For the De thermalibus aquis of Falloppio, we have used its second edition (Venice, 1569). On this work, see Thorndike, A History of Magic and Experimental Science, VI, 1941, 311-3; Giancarlo Zanier, Medicina e filosofia tra '500 e '600 (Milan, 1983), 5-19; Partington, A History of Chemistry, II, 100-1; Richard Palmer, "Pharmacy in the Republic of Venice in the Sixteenth Century," in Andrew Wear et al. (eds.), The Medical Renaissance of the Sixteenth Century (Cambridge, 1985), 100-17; 


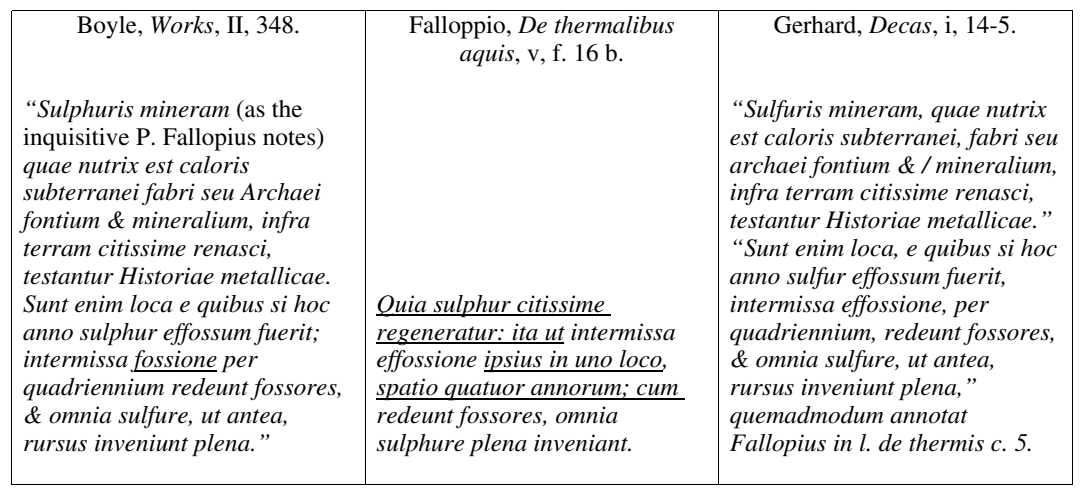

Boyle's initial phrase "Sulfuris mineram... Historiae metallicae" in fact is not found in Falloppio, but in Gerhard, whom Boyle is once more found to copy faithfully. But why did Boyle fail to recognize the beginning of the Falloppio quotation? It is because the text of Gerhard contains an unusual amount of italicized phrases, and the two parts in the present passage are not separated by any sign (although we added the break mark for clarity's sake). Boyle could thus not realize that the phrase in question was not Falloppio's, although the decidedly Paracelsian idea of subterranean workers as "the archeus of fountains and minerals" (archaei fontium et mineralium) is clearly not found in the Italian mineralogist, but presumably comes from the Paracelsian treatise De mineralibus or rather the (ps.-) Paracelsian De natura rerum..$^{30}$ The young Boyle, who did not show enough scepticism with respect to his sources, is likely to have committed this mistake because he did not take a look at Falloppio's text itself. Immediately after this quotation, Carneades invokes Pliny's report, but Boyle does not say whether he takes it from the original or continues instead quoting from Falloppio. But the situation is even more complex: while Falloppio does not state that he cites Strabo's testimony from Pliny's text, Boyle bases himself on Gerhard's interpretation of it all.

Giorgio E. Ferrari, "L'opera idro-termale di Gabriele Falloppio: le sue edizioni e la sua fortuna," Quaderni per la storia dell'Università di Padova 18 (1985), 1-41.

30 For an analysis of these two works, see Hirai, Le concept de semence, 183-95 and 210-3. 


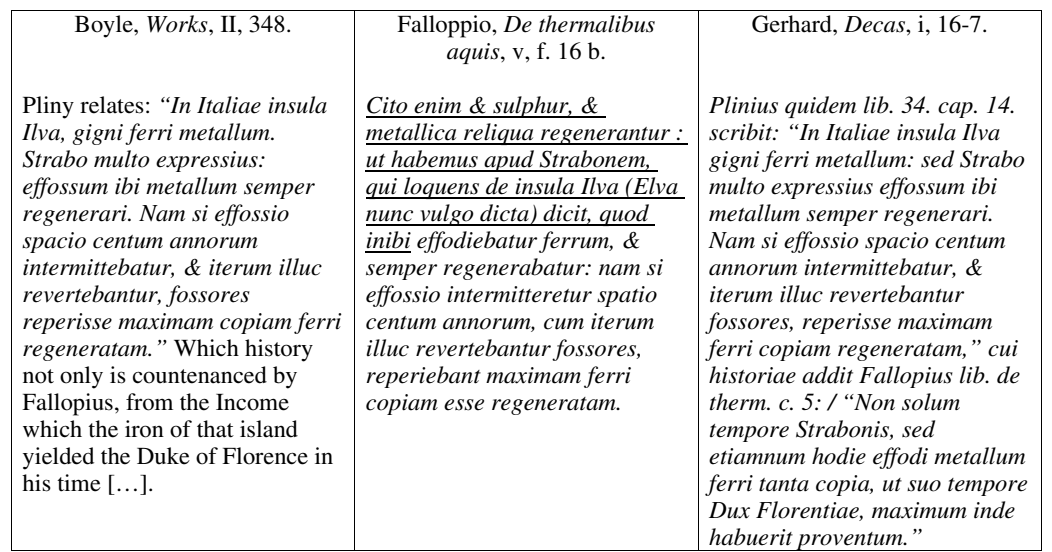

In Gerhard, Pliny's quotation is followed by Falloppio's, on the island of Elba, and Boyle paraphrases it in English. He then goes on to quote Cesalpino, but in reality only continues following Gerhard's doxographical compilation.

\begin{tabular}{|c|c|c|}
\hline Boyle, Works, II, 348. & $\begin{array}{c}\text { Cesalpino, De metallis, III, vi, } \\
183 .\end{array}$ & Gerhard, Decas, i, 17. \\
\hline $\begin{array}{l}\text { [...] but is mention'd more } \\
\text { expressely to our purpose, by } \\
\text { the learned Cesalpinus: "Vena } \\
\text { (sayes he) ferri copiosissima est } \\
\text { in Italia; ob eam nobilitata Ilva } \\
\text { Tirrheni maris insula incredibili } \\
\text { copia, etiam nostris temporibus } \\
\text { eam gignens: Nam terra quae } \\
\text { eruitur dum vena effoditur tota, } \\
\text { procedente tempore in venam } \\
\text { convertitur." }\end{array}$ & $\begin{array}{l}\text { Vena ejus [ferri] copiosissima } \\
\text { est in Italia: ob eam nobilitata } \\
\text { Ilva Tyrrheni maris insula, } \\
\text { incredibili copia etiam nostris } \\
\text { temporibus eam gignens: nam } \\
\text { terra quae eruitur, dum vena } \\
\text { effoditur, tota procedente } \\
\text { tempore in venam convertitur. }\end{array}$ & $\begin{array}{l}\text { Attestantur idem multo } \\
\text { luculentius Caesalpinus de } \\
\text { metall. lib. 3. cap. } 6 .: \text { "Vena, } \\
\text { inquiens, ferri copiosissima est } \\
\text { in Italia, ob eam nobilitata Ilva, } \\
\text { Tyrrheni maris insula } \\
\text { incredibili copia, etiam nostris } \\
\text { temporibus eam gignens: Nam } \\
\text { terra, quae eruitur, dum vena } \\
\text { effoditur tota, procedente } \\
\text { tempore in venam convertitur." }\end{array}$ \\
\hline
\end{tabular}

Since we have already encountered this passage in the "Growth of Metals," we are led to assume that this part of the Sceptical Chymist is based on the same reading note, which Boyle was to publish somewhat revised thirteenth years later, and that these two pieces are closely linked to the themes which attracted the young Boyle. In any case, he took this testimony as the most important evidence available that a certain type of earth might be transmuted into metal in the course of time by a "metallic plastic principle" residing in the earth. ${ }^{31}$

31 On the notion of seminal principle, see Hirai, Le concept de semence. For Boyle, see Antonio Clericuzio, "A Redefinition of Boyle's Chemistry and Corpuscular Philosophy," Annals of Science 47 (1990), 561-89, esp. 583-7; Hideyuki Yoshi- 
Carneades turns next to the greatest authority of Renaissance mineralogy, Agricola. He explains that although chymists regard this man as their adversary, Agricola also concedes the growth of metals, mentioning the case of the German town of Sagan: there, the ditches from which iron was extracted regenerate anew after ten years just like on Elba. Boyle provides in the margins the Latin text which is exactly the same as the one he quoted in the "Growth of Metals." ${ }^{2}$ The source is once more Gerhard, as a textual omission indicates.

\begin{tabular}{|c|c|c|}
\hline Boyle, Works, II, 348. & Agricola, De veteribus et novis & Gerhard, Decas, i, 17. \\
\hline $\begin{array}{l}\text { In Lygiis, ad Sagam oppidum; in } \\
\text { pratis eruitur ferrum, fossis ad } \\
\text { altitudinem bipedaneam actis. } \\
\text { Id decennio renatum denuo } \\
\text { foditur non aliter ac Ilvae } \\
\text { ferrum. }\end{array}$ & $\begin{array}{l}\text { Verum in Lygiis ad Sagam } \\
\text { oppidum e pratis eruitur ferrum, } \\
\text { fossis ad altitudinem } \\
\text { bipedaneam actis. Nec enim } \\
\text { propter abundantiam aquarum } \\
\text { altius agi possunt. Id decennio } \\
\text { renatum denuo foditur, non } \\
\text { aliter ac Ilvae ferrum. }\end{array}$ & $\begin{array}{l}\text { Ipse [Agricola] enim eodem } \\
\text { lib. } 2 \text { cap. } 15 \text { refert: "in Lygiis } \\
\text { ad Sagam oppidum in pratis } \\
\text { erui ferrum, fossis ad } \\
\text { altitudinem bipedaneam actis. } \\
\text { Id decennio renatum denuo fodi } \\
\text { non aliter ac Ilvae ferrum." }\end{array}$ \\
\hline
\end{tabular}

As in the case of lead, Boyle paraphrases Galen's report about the increase in volume and weight of this metal when used for the roofs of buildings or for the joints of statues. It is the same report that we have seen in the "Growth of Metals." In addition to this, he gives the testimony of the famous Italian writer Giovanni Boccaccio (1313-1375), whose words he says he had found quoted by "a diligent writer."

\begin{tabular}{|c|c|c|}
\hline Boyle, Works, II, 349. & Boccaccio, De montibus, [f. 9 r] & Gerhard, Decas, i, 22. \\
\hline $\begin{array}{l}\text { "Fessularum mons (sayes he) in } \\
\text { Hetruria, Florentiae civitati } \\
\text { imminens, lapides plumbarios } \\
\text { habet; qui si excidantur, brevi } \\
\text { temporis spatio, novis } \\
\text { incrementis instaurantur, ut } \\
\text { (annexes my author) tradit } \\
\text { Boccatius Certaldus, qui id } \\
\text { compertissimum esse scribit. }\end{array}$ & $\begin{array}{l}\text { Fesulae mons est biceps } \\
\text { Florentiae inclitae Tusciae } \\
\text { civitati supereminens, olivetis } \\
\text { plenus, ex quo si lapides qui } \\
\text { plumbei sunt excidantur, brevi } \\
\text { temporis spatio novis } \\
\text { incrementis restaurari } \\
\text { compertissimum est. }\end{array}$ & $\begin{array}{l}\text { "Fessularum mons in Hetruria, } \\
\text { Florentiae civitati imminens, } \\
\text { lapides plumbarios habet, qui si } \\
\text { excidantur, brevi temporis } \\
\text { spatio, novis incrementis } \\
\text { instaurantur, ut tradit Boccatius } \\
\text { Certaldus, qui id } \\
\text { compertissimum esse scribit." }\end{array}$ \\
\hline
\end{tabular}

moto, "Chemical Studies of Young Boyle: Their Helmontian Phase and the Seminal Principles," Kagakushi 19 (1992), 233-46; Peter R. Anstey, "Boyle on Seminal Principles," Studies in the History and Philosophy of Biology 33 (2002), 597-630.

32 The editors provide an erroneous reference to Agricola's De re metallica (1530 [sic!]). But the quote is neither from the Bermannus sive de re metallica (Basel, 1530) nor from the De re metallica libri XII (Basel, 1556), but from the De veteribus et novis metallis (Basel, 1546). We have used its first edition. 
Boyle, Works, II, 349.

Nihil hoc novi est: sed de eadem Plinius, lib 34. Hist. Natur. cap. 17. dudum prodidit, inquiens, mirum in his solis plumbi metallis, quod derelicta fertilius reviviscunt. In plumbariis secundo lapide ab Amberga dictis ad Asylum recrementa congesta in cumulos, exposita solibus pluviisque paucis annis, reddunt suum metallum cum fenore."
Boccaccio, De montibus, [f. 9 r]

Pliny, Natural History, XXXIV, 49 (164):

Mirum in his solis metallis, quod derelicta fertilius revivescunt.
Gerhard, Decas, i, 22.

Nihil hoc novi est, sed de eodem Plinius lib. 34. Historia naturalis cap. 17. dudum prodidit, inquiens: "Mirum in his solis plumbi metallis, quod derelicta fertilius reviviscunt." "In plumbariis secundo lapide ab Amberga dictis ad Asylum zu der Freyhung recrementa congesta in cumulos, exposita solibus pluviisque, paucis annis reddunt suum metallum cum foenore."

\section{Although it is possible to locate the quotation from Boccaccio} in his geographical treatise De montibus, sylvis, fontibus, we have already established that Boyle used the same extract in the "Growth of Metals," where he indicates his source precisely as the book by Gerhard, referring to its page number. ${ }^{33}$ By contrast, after the quotation from Pliny, Boyle's last sentence, "In plumbariis... fenore," does not appear in Pliny. By looking at Gerhard, we can easily understand what had happened. In his treatise, which, as mentioned, contains an unusual quantity of italicized phrases, not only Pliny is in italics, but also the report on the lead mines in the Bavarian Freihung near Amberg. Once the source is identified, we understand that this part of the quotation is neither from Boccaccio nor from Pliny, but from Boyle's "diligent writer," Gerhard. ${ }^{34}$

Suggesting lack of time, Carneades proposes to limit himself to only two or three additional reports. The first of them, he says, is from "Gerhardus the Physick Professor," who is here finally named explicitly.

$$
\text { Boyle, Works, II, } 349 .
$$

"In valle (sayes he) Joachimica argentum graminis modo \& more e lapidibus minerae velut e radice excrevisse digiti longitudine, testis est Dr. Schreterus, qui ejusmodi venas aspectu jucundas \& admirabiles domi suae aliis saepe monstravit \& donavit. Item aqua caerulea inventa est Annaebergae, ubi argentum erat adhuc in primo ente, quae coagulata redacta est in calcem fixi \& boni argenti."

\section{Garhard, Decas, i, 20.}

"In valle Joachimica argentum graminis modo \& more e lapidibus minerae, velut e radice excrevisse, digiti longitudine," testis est Doctor Schroeterus, qui ejusmodi venas aspectu jucundas \& admirabiles domi suae aliis saepe monstravit \& donavit. Item, "aqua caerulea inventa est Annaebergae, ubi argentum erat adhuc in primo ente, quae coagulata, redacta est in calcem fixi \& boni argenti."

33 Giovanni Boccaccio de Certaldo, De montibus, sylvis, fontibus... (Venice, 1473), without pagination [f. 9 r] = Tutte le opere di Giovanni Boccaccio (Milan, 1998), v. VII-VIII, t. 2, 1848.

34 Boyle eliminated the German inscription "zu der Freyhung," because he probably could not understand why it was there. 
It is evident how faithfully Boyle quotes Gerhard.$^{35}$ It is the first time in this treatise that Boyle gives the name of this author, although, as we have shown, he has been dependant on him all along. ${ }^{36}$ Note that he presents Gerhard as if this man were not the same person as the one that he has just referred to as the anonymous "diligent writer."

After these testimonies from the Latin authors "of good credit," Boyle wants to add two more, both recorded only in German. The first one comes from the commentary of Johann Walch ( $c a$. 1551-after 1620) on the alchemical treatise, Der kleine Bauer (Frankfurt, 1617), of Johann Grasse or Grasshoff (ca. 1560-1618). Grasse was a medical advisor to Ernest of Bavaria (1554-1612), the princebishop of Cologne-Liege as well as a cousin of the emperor Rudolf II (1576-1612). ${ }^{37}$ His Der kleine Bauer itself was widely read during the seventeenth century. The second testimony is taken from the commentary of Johann Agricola (ca. 1589-ca. 1670) on the treatise Chymische Medicin (Frankfurt, 1617) of the German chymist Johann Poppius (1577-?). ${ }^{38}$

Based on all these testimonies, Carneades eventually concludes that the three principles of the chymists are unnecessary for the constitution of metals in mines. His discourse continues along the same lines for twenty more pages, until the end of the dialogue. Importantly, then, the chain of testimonies by Continental authors analyzed above forms the core of the last part of the Sceptical Chymist. By manipulating his sources, Boyle conveys the impression that he is relying on a very wide array of authors. In reality, he only uses a single source for the Latin authors and does not even check whether Gerhard's quotations are exact or

35 Thus, the editors' note is doubly in error for the name of Johann Conrad Gerhard and for the dates of birth and death (1582-1637), which are those of the Lutheran theologian and not of two chymists.

36 We have not been able to identify this "Schroeterus."

37 On Grasse, see Thomas Lederer, Der Kölner Kurfürst Herzog Ernst von Bayern (1554-1612) und sein Rat Johann Grasse (um 1560-1618) als Alchemiker der frühen Neuzeit: Ein Beitrag zur Geschichte des Paracelsismus, Ph. D. diss. (University of Heidelberg, 1992); id., "Leben, Werke und Wirkung des Stralsunder Fachschriftstellers Johann Grasse (nach 1560-1618)," in Wilhelm Kühlmann and Horst Langer (eds.), Pommern in der frühen Neuzeit: Literatur und Kultur in Stadt und Region (Tübingen, 1994), 227-37. On Ernest of Bavaria, see also Robert Halleux and Anne-Catherine Bernès, "La cour savante d'Ernest de Bavière," Archives internationales d'histoire des sciences 45 (1995), 3-29.

38 On Johann Agricola, see his letter to Boyle (6 April 1668) in Boyle, Correspondence, IV, 59. 
even authentic. Admittedly, Boyle was some years later to introduce a more mechanical explanation into his "Growth of Metals". But that does not change the fact that this part of the Sceptical Chymist is based on the same reading note.

\section{Johann Gerhard and his chymico-mineralogical work (1643)}

We shall now briefly analyze the work of Gerhard, Ten Best-Known Physico-Chymical Questions on Metals. This treatise of 130 pages in octavo is divided into ten chapters each of which is devoted to one specific "chymical" problem.

1. Does nature still generate and regenerate metals? (29 pages)

2. Are metals composed of mercury and sulfur? (21)

3. Is heaven the efficient cause of metals, and is there goldmaking power in the stars? (31)

4. Where to find the seed, the aliment and the propagation of gold and metals? (14)

5. Can metals be divided into imperfect and perfect ones? (6)

6. Does nature always tend towards gold in the generation of metals? (4)

7. Can art imitate the nature in the generation of gold? (7)

8. Can art make gold more perfect? (10)

9. Can different species of metals be transformed into one another? (11)

10. Does the separation of the form of gold from its matter produce the philosophers' tincture? (5)

The largest space is given to the first three questions. Although Boyle uses only the first chapter, as far as we could see, let us examine some major points of his work so as to understand Gerhard's method and the nature of his treatise.

Gerhard's method is a fusion of the Renaissance humanists' concern for textual problems with that of the medieval alchemists' doxographical interests, as evidence in the famous Rosarium philosophorum (Frankfurt, 1550). ${ }^{39}$ His text abounds in quotations from diverse writers, and each chapter compiles the ideas of ancient, medieval and modern authors on a specific question.

39 See Joachim Telle et al. (eds.), Rosarium philosophorum: Ein alchemisches Florilegium des Spätmittelalters (Weinheim, 1992). 
This makes his treatise an easy-to-use doxography, a kind of florilegium or commonplace-book on these ten chymical problems. Like many Renaissance humanists, Gerhard is explicit about the source materials he uses when their authority is well established (although he probably also hides his direct sources, like many of his contemporaries). Among the numerous authorities he uses, his favorites are Aristotle, Theophrastus, Galen and Pliny among the ancients, and Avicenna and Albertus Magnus among the medievals. As for Renaissance writers, he often quotes Agricola, Cardano, Falloppio and Cesalpino. Up to here, his choice of author may be said to be typical of Renaissance mineralogists like Cesalpino. In addition, he frequently refers to sixteenthcentury Aristotelian philosophers like Julius Caesar Scaliger, Jacopo Zabarella and Jakob Schegk (1511-1587) of Tübingen, which adds an academic flavor to his work. However, what is most remarkable about him and distinguishes him from other Renaissance mineralogists is his abundant use of medieval alchemists like Petrus Bonus, Arnald of Villanova and particularly pseudo-Geber. ${ }^{40}$ To this list, we must finally add a series of Renaissance alchemical treaties ascribed to Marsilio Ficino, Giovanni Francesco Pico della Mirandola, Bernardus Trevisanus, Deny Zacaire, Basil Valetin and Jean d'Espagnet. Gerhard also uses Paracelsian treatises, which include not only authentic works but also some of doubtful authenticity such as the De natura rerum and the Philosophy for Athenians, two works with a particularly strong affinity with medieval alchemy.

With his dense texture of quotations, Gerhard wants to achieve a defense of the transmutatory art against "anti-chymists" and the harmonization of diverse opinions not only among the chymists themselves but also between these chymists and the Renaissance mineralogists. As we have shown elsewhere, the fusion of Renaissance mineralogy in the tradition of Agricola with Paracelsian chymistry took place in the beginning of the seventeenth century in a work entitled Gemmarum et lapidum historia (Hanau, 1609). This treatise is considered the most important minera-

40 Cf. William R. Newman, The Summa perfectionis of Pseudo-Geber (Leiden, $1991)$; id., "L'influence de la Summa perfectionis du pseudo-Geber," in Jean-Claude Margolin and Sylvain Matton (eds.), Alchimie et philosophie à la Renaissance (Paris, 1993), 65-77. On the ps.-Geber in Boyle, see Lawrence M. Principe, The Aspiring Adept: Robert Boyle and his Alchemical Quest (Princeton, 1998), 153-5. 
logical work of that century. Its author is Anselmus Boetius de Boodt (1550-1632), a mineralogist at the court of emperor Rudolf II. ${ }^{41}$ What is significant about this work is the fact that, while providing natural explanations for "occult" powers traditionally ascribed to precious stones, de Boodt advanced the theories of "architectonic sprit" and its "seminal power" for mineral formation under the clear influence of Paracelsians such as Petrus Severinus (1540/42-1602) and Joseph Du Chesne alias Quercetanus (1546-1609). ${ }^{42}$ Several writers, among others Daniel Sennert (15721637), followed in this path, and we may also place Gerhard in the context of this nascent tradition. What is characteristic of his work is, however, the fact that he pushes this fusion to its extreme by searching the harmony of the ideas of Paracelsus himself with the dominant current of the medieval alchemy of pseudo-Geber. ${ }^{43}$

\section{How did Boyle know Gerhard's treatise?}

The treatise by Gerhard is very rare, and there exists very little information about his life and his work's influence. How could Boyle know of this treatise and obtain it? In his correspondence, his work diary and the manuscripts in the Boyle Papers, we have found no trace of Gerhard. The correspondence of Henry Oldenburg did not help us either.

41 Boyle estimates de Boodt as "the best author" on the subject. Cf. Usefulness (Works, III, 418, 422-3); Clayton's Diamond (Works, IV, 189, 194-5); Origin and Virtues of Gems (Works, VII, 7, 19). On de Boodt, see Hirai, Le concept de semence, 37599; id., "Les Paradoxes d'Etienne de Clave et le concept de semence dans sa minéralogie," Corpus 39 (2001), 45-71; DSB 2 (1970), 292-3; Thorndike, A History of Magic and Experimental Science, VI, 318-24; Robert Halleux, "L'œuvre minéralogique d'Anselme Boèce de Boodt (1550-1632)," Histoire et Nature 14 (1979), 63-78.

42 On Quercetanus, see Hiro Hirai, "Paracelsisme, néoplatonisme et médecine hermétique dans la théorie de la matière de Joseph Du Chesne à travers son Ad veritatem hermeticae medicinae (1604)," Archives internationales d'histoire des sciences 51 (2001), 9-37; Didier Kahn, "L'interprétation alchimique de la Genèse chez Joseph Du Chesne dans le contexte de ses doctrines alchimiques et cosmologiques," in Barbara Mahlmann-Bauer (ed.), Scientiae et artes: Die Vermittlung alten und neuen Wissens in Literatur, Kunst und Musik (Wiesbaden, 2004), 641-92.

43 Gerhard, Decas, iii, 46-50. On the Geberian theory of "mercury alone," see Thorndike, A History of Magic and Experimental Science, III, 58; Newman, The Summa perfectionis of Pseudo-Geber, 204-8; id., Gehennical Fire: The Lives of George Starkey, an American Alchemist in the Scientific Revolution (Cambridge MA, 1994), 86, 99; Hirai, Le concept de semence, 30-1, 342-5. 
We had more luck when looking at the Certain Physiological Essays, where Boyle discusses the regeneration of minerals. Among the mineralogical themes that attracted his attention, there is that concerning a special mineralizing juice called "Gur," "Ghur" or "Guhr." Boyle notes that this word is only mentioned in one or two German treatises, one of which was Mathesius' Sarepta, which he could not, however, read because it was written in German. ${ }^{44}$ We have seen that he quotes Mathesius through Gerhard's work. But we could find neither "Gur" nor Agricola's closer idea, "lapidifying juice" (succus lapidescens) in Gerhard's Decas. Our clue to Boyle's real source was provided in the Metallographia (London, 1671) by John Webster (1611-1682) and in A Philosophical Essay (London, 1672) by Thomas Sherley (16381678). These two close followers of Boyle's mineralogy explained the way in which the idea of "Gur" had been transmitted to him. ${ }^{45}$ They report that this word occurred in a Latin treatise entitled Arca arcani artificiosissimi de summis naturae mysteriis, included in the sixth and last volume of the Theatrum chemicum of the Zetzner press (Strasbourg, 1661) ${ }^{46}$ But this work is in fact a translation of Der grosse Bauer and Der kleine Bauer by Johann Grasse. Boyle himself must have heard of the reputation of Grasse's work, at the latest in 1659, when Samuel Hartlib (ca. 1600-1662) explained to him in two letters that in his house, a certain "young Clodius" was translating a German treatise called "Bauer" for Boyle. ${ }^{47}$ Thus, Hartlib's circle seems to have played an important

44 Boyle, Certain Physiological Essays (Works, II, 197); Generation of Minerals (Works, XIII, 368). In his article on the mines in the Philosophical Transactions (19 November 1666) (Works, V, 529-40), Boyle touches on a report of Mathesius (536, n. b). In mentioning "Gur" (539), he refers in its second version of 1692 to Van Helmont, probably having the Helmontian idea of "Bur" in mind. On "Gur," see Mathesius, Sarepta, iii, in Ausgewählte Werke (Prague, 1904), IV, 168, 179, 199, 210.

${ }^{45}$ See John Webster, Metallographia (London, 1671), 50; Thomas Sherley, A Philosophical Essay (London, 1672), 50-2. On Webster, see DSB 14 (1976), 209-10; Allen G. Debus, The Chemical Philosophy (New York, $\left.{ }^{1} 1977 / 22002\right)$, 393-400, 402-9, 457-8, 514-7; Antonio Clericuzio, "Alchimie, philosophie corpusculaire et minéralogie dans la Metallographia de John Webster," Revue d'histoire des sciences 49 (1996), 287-304. On Sherley, see Allen G. Debus, "Thomas Sherley's Philosophical Essay (1672): Helmontian Mechanism as the Basis of a New Philosophy," Ambix 27 (1980), 124-35; Oldroyd, "Some Neo-Platonic and Stoic Influences on Mineralogy," 143-6.

${ }_{46}$ Johann Grasse, Arca arcani artificiosissimi, in Theatrum chemicum (Strasbourg, 1661), VI, 294-381, esp. 306, 318 on Gur. Cf. Ferguson, Bibliotheca chemica, I, 33841; Lederer, Der Kölner Kurfürst Herzog Ernst von Bayern, 252-6.

47 See Hartlib's letters of 30 April and 10 May 1659 (Boyle, Correspondence, I, 
role in the transmission of the idea of "Gur." Might the same thing be true about Gerhard's work? Unfortunately, our research on the Hartlib Papers has to date not yielded conclusive evidence on this issue.

Nevertheless, we have encountered another interesting fact. In the fourth essay, which constitutes an addition, datable to around 1660, to the Usefulness of Natural Philosophy (1663), which in turn was composed around 1649, Boyle speaks of a certain doctor "Jo. Conradus Gerhardus." According to Boyle, this man wrote a small treatise called "Physico-Chymical Questions," which contains testimonies about the continuous growth of metals. He says:

To prove that metalline bodies were not all made at the beginning of the world, but have some of them a power, though slowly to propagate their nature when they meet with a disposed matter; you may finde many notable testimonies and relations in a little book of Physico-chymical Questions, written by Jo. Conradus Gerhardus, a Germane doctor, and most of them recited (together with some of his own) by the learned Sennertus. ${ }^{48}$

This "Jo. Conradus Gerhardus" should be Johann Conrad Gerhard (1567-after 1623), the father of our Gerhard. He was a chymist and physician of the German prince Wolfgang II of Hohenlohe (1546-1610) and the author of a treatise called Extractum chymicarum quaestionum de lapide philosophorum (Strasbourg, 1616), but not of the Decas quaestionum physico-chymicarum. ${ }^{49}$ Here Boyle probably confused the father and the son, just like Pierre Borel (ca. 16201671) in his famous inventory of chymical treatises, the Bibliotheca chimica (Paris, 1654). ${ }^{50}$ But that is not all: Boyle also explains that the testimonies of Conrad Gerhard were quoted by Daniel Sennert. After this passage, he adds the observations of Van

345, 350). Hartlib also speaks of the "Kleine Bauer" in a letter to Oldenburg (2 December 1658). Cf. Hall and Hall, The Correspondence of Henry Oldenburg, I, 1927. Hartlib knew the "Bauer" at least since 1648/9. See Hartlib Papers, 28/1/6A. 48 Boyle, Usefulness, I, iv, 79-80 (Works, III, 254).

49 On Conrad Gerhard, see Ferguson, Bibliotheca chemica, I, 312-3; Carlos Gilly, Johann Valentin Andreae, 1586-1986 (Amsterdam, 1986), 47; Jost Weyer, Graf Wolfgang II. von Hohenlohe und die Alchemie: Alchemistische Studien in Schloss Weikersheim (Sigmaringen, 1992), 393-4; Julius Paulus, "Alchemie und Paracelsismus um 1600: Siebzig Porträts," in Joachim Telle (ed.), Analecta Paracelsica: Studien zum Nachleben Theophrast vom Hohenheims im deutschen Kulturgebiet der frühen Neuzeit (Stuttgart, 1994), 335-406, esp. 357.

50 Borel inverses the works of the father and the son in his Bibliotheca chimica (Heidelberg, 1656; repr. Hildesheim, 1969), 98-9. On Borel, see Pierre Chabbert, "Pierre Borel (1620 ?-1671)," Revue d'histoire des sciences 21 (1968), 303-43. 
Linschoten and Garcia da Orta on the growth of diamonds, which we have already encountered in the Sceptical Chymist. Given Boyle's quoting habits, we can think that in this passage, he was relying exclusively on Sennert's text rather than on Conrad Gerhard.

Let us turn to Sennert himself. Boyle does not provide any additional information regarding the passage in question. But since the editors of the new edition of his Works correctly suggest the treatise De chymicorum cum Aristotelicis et Galenicis consensu et dissensu (Wittenberg, ${ }^{1} 1619,{ }^{2} 1629$ ) as his source, we have been able to find the passage in chapter nine (whose relevant parts are reproduced below, in our Appendix), where Sennert interprets the concept of seeds as set out by the Danish Paracelsian Petrus Severinus. ${ }^{51}$ Having explained all the main theories on the origin of forms, which had been advanced by philosophers and chymists, Sennert takes up the formation of minerals. His discussion is followed by a series of reports on the regeneration of metals which he draws from "Joh. Conradus Gerhardus."52 Here, we find some of the same testimonies by Continental authors with which we are already familiar, such as Pliny, Boccaccio, Falloppio, Cesalpino and Garcia da Orta. Most of the elements of this passage were to be found once again in the text of Johann Gerhard in a revised way and italicized. After quoting Conrad Gerhard, Sennert himself continues his discussion by referring to de Boodt's theory of the "architectonic spirit" and its "seminal power" for mineral formation. Accepting these theories, he ends his chapter.

This, in turn, makes us conjecture that the young Boyle first encountered the name of Johann Conrad Gerhard and the title of his treatise when reading Sennert's work. As he was greatly interested in testimonies on the growth of metals, he wanted to obtain Gerhard's book. But what Boyle eventually obtained was not the work by Conrad Gerhard, but by his son. And although both the title and the author's name differed slightly from what he sought, since he found in this book what he had been looking for, he was happy enough with it.

But two questions still remain: first, did Boyle also obtain the

51 Sennert, De chymicorum consensu et dissensu, ix, 85-114. We have used its third edition (Paris, 1633). Boyle probably used this edition too. For an analysis of the chapter, see Hirai, Le concept de semence, 401-6.

52 Sennert, De chymicorum consensu et dissensu, 112-3. 
treatise of Conrad Gerhard and, second, did he ever come to realize that he confused two books and two authors?

\section{Conclusions}

In this study, we have examined in detail some key testimonies concerning the growth of metals, which the young Boyle quoted from several Continental authors. By means of our surgical analysis, we have identified the main source of a series of his quotations and have clarified the way in which he used this source material to increase the credibility of his discourse. Although he offered numerous quotations, by which he wished to impress his readers, we have concluded that the young Boyle probably did not consult the works he was quoting. In reality, he was largely dependant on a single, small, but very useful doxographical compendium. This discovery makes one suspect that Boyle used the same kind of method in other fields such as pharmacology, natural history, chemistry and even philosophy. ${ }^{53}$

Finally, we must once more emphasize the role played by Sennert. Not only did he provide a crucial link between Gerhard and Boyle, but also his discussion of the concept of seeds touched upon issues such as spontaneous generation, mineral formation and de Boodt's ideas of the "architectonic spirit" and its "seminal power," all of which fascinated the mind of the young Boyle. ${ }^{54}$

\section{Appendix}

Daniel Sennert, De chymicorum cum Aristotelicis et Gelenicis consesu et dissensu, cap. 9 (Paris, ${ }^{3} 1633$ ).

(p. 112 b) [margin: Historiae metallorum renascentium] Qua de re doctorum virorum observationes collegit, in Extracto quaestionum chymicarum de lapide philosophorum Joh. Conradus

53 For related issues, we acknowledge Harriet Knight to have shown us her Organising Natural Knowledge in the Seventeenth Century: The Works of Robert Boyle, Ph. D. diss. (University of London, 2003).

54 On Kircher's theory on spontaneous generation in which Boyle was interested, see Hiro Hirai, “De novo' or 'ex semine': Kircher and the Problem of Spontaneous Generation," paper read in the international colloquium Scientific Culture in Early Modern Rome (11 October 2003, Warburg Institute, London). 
Gerhardus, M. D. contra eos, qui statuunt, omnia metalla, quae hactenus e terra effossa sunt, et posthac effodientur, simul in prima creatione condita esse, et nulla amplius crescere. Aurum Corbachiae in Westphalia crescit et recrescit in cumulis singulis quadrienniis. Sic argentum in cumulis plumbi cinerei, ubi prius nullum inerat argentum, certo tempore maturatur et perficitur. Item vena plumbi in Sclavonia quadragesimo anno transit in argentum. Squama aeris arena sicca anno trigesimo in aurum. Ferrum in Silesia ad Saganum oppidum decimo renatum anno denuo foditur; non aliter ac in Ilva ferrum, quae est Italiae Insula in Thyrreno mari. In Misnia limus ruber palustris quiquennio; In Svecia similis limus uno anno Soli expositus, in bonum ferrum abit. Idem in cumulis ex lapide fissili usu venit, circa aurifodinas Mansfeldiae, ubi aes similiter maturatur et renascitur. Fessularum mons in Hetruria lapides plumbarios habet, qui si exscindantur, brevi temporis spatio novis instaurantur incrementis, ut tradit Bocarius (p. 113 a) Certaldus, qui id compertissimum esse scribit. Plinius etiam, lib. 34. cap. 17. scribit: "Mirum in his solis plumbi metallis, quod derelicta fertilius reviviscant." Sed id non in solis plumbi, verum in omnibus metallis usu venit; imo et mineralibus. De ferro, quod in Ilva Thyrreni maris Insula effoditur, refert Andreas Caesalpinus, lib. 3. De metallicis cap 6. terram inanem metalli, quae eruitur, dum vena effoditur, totam procedente tempore in venam converti. Sulphuris vena quadriennio reparatur, ut refert Fallopius, De thermis cap 5. Terra detracta halonitro in cumulum redacta post 5 . aut 6 . annos nitrum reddit, ut scribit Cardanus, lib. De subtilitate. In India montem esse Oromenum appellatum salis nativi, in quo lapidicinatum modo cedatur sal renascens, refert Caesalpinus, De metallicis, lib. 1 cap. 16.

Neque est, ut quis hic subterfugium aliquod quaerat et obtendat; forsan lapides illos vejectos in cumulos metalla jam olim in se continuisse. Aliud enim explotatio exactissima probatorum docet, qui ne minimum fere granum in scoriis relinquunt. Et plane in signe ac notatu dignum est, quod Garcias ab Horto, Simplc. in Ind. nasc. lib. 1. cap. 47. de adamante ita scribit: "Adamantes, qui altissime in terrae visceribus, multisque annis perfici debebant, in summo fere solo generantur, et duorum aut trium annorum spacio perficiuntur. Nam si in ipsa fodina hoc anno ad cubiti altitudinem fodinas, adamantes reperies. Post biennium, rursus illic (p. 113 b) excavata, ibidem invenies adamantes."

Neque absurdum videtur, in mineris spiritum aurificum vel 
argentificum cum materia idonea coalescere et aurum vel argentum fieri; aurumque et argentum hoc, antequam solidescat, et excoquatur, iterum a se posse spiritus argentificos et aurificos emittere, qui materiam dispositam in aurum vel argentum convertant; et hoc modo perpetuari metallorum fodinas. Quod certe ipsi ductus et fluxus venarum metallicarum monstrare videntur, in quibus quid naturae vegetabili apparet. Idemque et hoc confirmare videtur, quod a medico quodam experientissimo, qui diu Fribergae, fodinis metallicis nobili Misniae oppido, medicinam fecit, relatum scio. Is enim cum aliquos ex fossoribus metallicis mortuos apervisset, in pulmonibus ea ipsa metalla concreta reperit, in quibus effodiendis vivi laboraverant.

An tamen proprie crescere dici possint, dubitatur. J. C. Scaliger, in lib. 1. De plantis, lapides crescere negat: "Lapides, inquit, crescunt, sed augescunt. Sic obtinebit augmentum generis proportionem ad incrementum. Ut illud sit apposita cujuscumque modi quantitate: incrementum fiat occupationum, quoquo versum capacioris loci ex promotione ambitus extimi, admissis intro partibus, mutatis atque unitis."

Unde semen metallis et mineralibus si non univocum, certe analogum nonnulli tribuendum (p. 114 a) censent. Hoc certum esse puto, formas istas, seu semina seu seminarias rationes, ut aliarum etiam rerum, a Deo primum creatas esse, ut rerum sui generis sint principia. Et licet formae istae ac seminaria principia in animalibus et plantis plerisque per certa corpora, quae semina dicuntur, propagentur, et peculiari corpore spiritus ille architectonicus concludatur, in metallis tamen per totum corpus dispergitur. Quod enim in salice et aliis plantis fieri videmus, ut per ramum avulsum fiat propagatio, utpote in quibus seminale principium per totam plantam, dispergitur: idem in metallis et gemmis accidit, in quibus formale illud, aut si ita libeat appellare, seminale principium, seu spiritus architectonicus in materia metallica seu lapidescente occulto modo conclusus est. Qui plura hac de re cognoscere cupit, legat cap. 13. lib De lapidibus et gemmis, Anselmi Boetii, in quo postquam multis de figura sexangulari cristallorum et aliis gemmarum figuris disputavit, tandem concludit; se autumare naturam, ut cristallus hac nota ab aliis gemmis distingueretur, ipsi hexagonam figuram dedisse, non secus quam arborum frondibus et herbarum floribus peculiares suas figuras dedit, quae ab architectonico spiritu et formatrice facultate ignoto nobis modo fabricentur. 